\title{
Suicide attempts among activated soldiers in the U.S. Army reserve components
}

\author{
James A. Naifeh', Robert J. Ursano ${ }^{1 *} \mathbb{D}$, Ronald C. Kessler², Oscar I. Gonzalez', Carol S. Fullerton?', \\ Holly B. Herberman Mash', Charlotte A. Riggs-Donovan', Tsz Hin Hinz Ng'1, Gary H. Wynn', Hieu M. Dinh', \\ Tzu-Cheg Kao ${ }^{3}$, Nancy A. Sampson ${ }^{2}$ and Murray B. Stein ${ }^{4,5}$
}

\begin{abstract}
Background: Although the majority of active duty U.S. Army soldiers are full-time personnel in the Active Component (AC), a substantial minority of soldiers on active duty are in the Reserve Components (RCs). These "citizen-soldiers" (Army National Guard and Army Reserve) represent a force available for rapid activation in times of national need. RC soldiers experience many of the same stressors as AC soldiers as well as stressors that are unique to their intermittent service. Despite the important role of $\mathrm{RC}$ soldiers, the vast majority of military mental health research focuses on AC soldiers. One important goal of the Army Study to Assess Risk and Resilience in Servicemembers (Army STARRS) is to address this gap. Here we examine predictors of suicide attempts among activated RC soldiers.
\end{abstract}

Methods: This longitudinal, retrospective cohort study used individual-level person-month records from Army and Department of Defense administrative data systems to examine socio-demographic, service-related, and mental health predictors of medically documented suicide attempts among activated RC soldiers during 2004-2009. Data from all 1103 activated RC suicide attempters and an equal-probability sample of 69,867 control person-months were analyzed using a discrete-time survival framework.

Results: Enlisted soldiers comprised $84.3 \%$ of activated RC soldiers and accounted for $95.7 \%$ of all activated RC suicide attempts (overall rate $=108 / 100,000$ person-years, more than four times the rate among officers). Multivariable predictors of enlisted RC suicide attempts included being female, entering Army service at age $\geq 25$, current age $<30$, non-Hispanic white, less than high school education, currently married, having 1-2 years of service, being previously deployed (vs. currently deployed), and history of mental health diagnosis (particularly when documented in the previous month). Predictors among RC officers (overall rate $=26 / 100,000$ person-years) included being female and receiving a mental health diagnosis in the previous month. Discrete-time hazard models showed suicide attempt risk among enlisted soldiers was inversely associated with time in service.

Conclusions: Risk factors for suicide attempt in the RCs were similar to those previously observed in the AC, highlighting the importance of research and prevention focused on RC enlisted soldiers in the early phases of Army service and those with a recent mental health diagnosis.

Keywords: Military, Suicide attempt, Risk factors, Army National Guard, Army reserve

\footnotetext{
* Correspondence: robert.ursano@usuhs.edu

${ }^{1}$ Center for the Study of Traumatic Stress, Department of Psychiatry,

Uniformed Services University of the Health Sciences, 4301 Jones Bridge

Road, Bethesda, MD 20814, USA

Full list of author information is available at the end of the article
}

(c) The Author(s). 2019 Open Access This article is distributed under the terms of the Creative Commons Attribution 4.0 International License (http://creativecommons.org/licenses/by/4.0/), which permits unrestricted use, distribution, and reproduction in any medium, provided you give appropriate credit to the original author(s) and the source, provide a link to the Creative Commons license, and indicate if changes were made. The Creative Commons Public Domain Dedication waiver (http://creativecommons.org/publicdomain/zero/1.0/) applies to the data made available in this article, unless otherwise stated. 


\section{Background}

Rates of non-fatal suicide attempts and suicide deaths among U.S. Army soldiers increased during the wars in Iraq and Afghanistan [1-3], with elevated risk persisting among veterans who have left the military $[4,5]$. Most research on non-fatal suicide attempts has focused on the full-time soldiers within the Army's Active Component (AC) (e.g., [6-8]). Suicide attempts among soldiers in the Reserve Components (RCs), which also increased during the wars [9], have received much less attention. The RCs include the Army National Guard and Army Reserve, comprising approximately $53 \%$ of the total Army population (all active and inactive soldiers) in 2017 [10]. These "citizen-soldiers" augment the AC as needed during wartime, returning to their communities, civilian jobs, and/ or college studies after deployment. In addition to their unique role and circumstances, $\mathrm{RC}$ soldiers may differ from the $\mathrm{AC}$ on mental health outcomes (e.g., stress, anxiety, and depression) and risk for suicide ideation and attempt [11-14]. Improved understanding of suicide attempt risk within the RCs can inform targeted intervention programs for this substantial proportion of the Army population.

Most previous findings on non-fatal suicidal events within the RCs are based on survey research (e.g., [15-17]). Few studies have examined suicide attempts documented in the administrative medical records of RC soldiers, which are particularly important owing to their impact on the Army healthcare system. Univariable analyses indicate that documented attempts are more likely among RC soldiers who are female, younger, less educated, and never married [9]. Here we used 2004-2009 administrative data from the Army Study to Assess Risk and Resilience in Servicemembers (Army STARRS) to examine multivariable associations of socio-demographic, service-related, and mental health predictors with suicide attempts among activated RC soldiers.

\section{Methods \\ Sample}

The Historical Administrative Data Study (HADS) is a component of Army STARRS that integrates deidentified records from 38 Army and Department of Defense administrative data systems [18]. The study was approved by the institutional review boards of the Uniformed Services University, University of California, San Diego, Harvard Medical School, and University of Michigan Institute for Social Research. In this longitudinal, retrospective cohort study, we focused on the active-duty person-month records for the 743,171 RC soldiers (i.e., U.S. Army National Guard and U.S. Army Reserve) who were federally activated under Title 10 from January 1, 2006 through December 31, 2009. During that time there were 1103 RC soldiers with a documented suicide attempt (1056 enlisted soldiers, 47 commissioned and warrant officers). Personmonth data were analyzed using a discrete-time survival framework [19], with each month in a soldier's career treated as a separate observational record. In order to reduce computational intensity, we selected an equalprobability 1:200 sample of 69,867 control personmonths (58,895 enlisted soldiers, 10,972 officers). When control person-months are randomly subsampled and weighted, discrete-time survival coefficients can be estimated without bias [20]. Prior to selection, the population of control person-months was stratified by gender, rank, time in service, deployment status (never deployed, currently deployed, or previously deployed), and historical time. The control sample excluded all person-months in which a soldier died or had an administratively documented non-fatal suicidal event (e.g., suicide attempt, suicide ideation) [3]. To adjust for under-sampling, control person-months were weighted to 200 .

\section{Measures}

Administratively documented suicide attempts were identified using Department of Defense Suicide Event Report (DoDSER) records and ICD-9-CM E950-E958 diagnostic codes (indicating self-inflicted poisoning or injury with suicidal intent). The DoDSER is a suicide surveillance program in which medical providers at DoD treatment facilities use a standardized reporting form to document suicidal behaviors [21]. The Military Health System Data Repository, Theater Medical Data Store, and TRANSCOM (Transportation Command) Regulating and Command and Control Evacuating System (Additional file 1: Table S1) were used to identify ICD-9-CM E950-E958 codes documented during healthcare encounters at military and civilian treatment facilities, as well as during combat operations and aeromedical evacuations. Records indicating suicide death or only suicide ideation (without an attempt) were excluded. We also excluded the E959 code (late effects of a self-inflicted injury) because it confounds the temporal associations between risk factors and suicide attempts [22]. Crossreferencing of the different data systems was conducted to ensure that all cases represented unique soldiers. When multiple suicide attempts were documented for a single soldier, a hierarchical classification scheme was used to select the first attempt [3]. Administrative records were also used to construct variables for socio-demographic characteristics (gender, age at entry into Army service, current age, race, education, and marital status), active time in service (based on the number of months an $\mathrm{RC}$ soldier was activated), deployment status (never deployed, currently deployed, or previously deployed), and previous mental health diagnosis (Additional file 1: Table $\mathrm{S} 1)$. The indicator for any previous mental health diagnosis was constructed using ICD-9-CM mental disorder 
codes, excluding postconcussion syndrome, tobacco use disorder, and supplemental V-codes (Additional file 1: Table S2). Recency of mental health diagnosis was determined by calculating the number of months between the most recently recorded diagnosis and the subsequent suicide attempt (cases) or sampled person-month (controls).

\section{Analysis methods}

Analyses were conducted using SAS version 9.4 [23]. Enlisted soldiers and officers were examined separately owing to their different socio-demographic profiles, Army training and career experiences [24], and risk of mental health problems [25-27] and suicidal behaviors [8, 28-30]. Discrete-time person-month survival analysis with a logistic link function was used to examine multivariable associations of socio-demographic characteristics with suicide attempt. This was followed by a series of multivariable models (adjusting for the socio-demographic variables) that separately examined the incremental predictive effects of active time in service, deployment status, and presence/recency of a previous mental health diagnosis. Due to the small number of activated RC officers with a documented suicide attempt, some of the predictor categories had to be combined in subsequent officer analyses. Odds-ratios (ORs) and 95\% confidence intervals (CI) were obtained by exponentiating the logistic regression coefficients. Using coefficients from the final model, we generated a standardized risk estimate (SRE; [31]) (number of suicide attempters per 100,000 person-years) for each predictor category. The SREs assume other predictors in the final model are at their sample-wide means. A dummy predictor for calendar month and year was included in all logistic regression equations to control for secular trends in suicidal behaviors during the study period $[1-3,9,32]$. Among enlisted soldiers (the number of officer cases was insufficient), changes in suicide attempt risk across active time in service were further examined in a discrete-time survival model that estimated risk (suicide attempters per 100,000 person-months) in each active month since entering the Army.

\section{Results}

\section{$\mathrm{RC}$ suicide attempt rates by rank}

Enlisted soldiers comprised $84.3 \%$ of activated RC soldiers, accounted for $95.7 \%$ of activated RC suicide attempters $(n=1056)$, and had an overall suicide attempt rate of $108 / 100,000$ person-years $(95 \% \mathrm{CI}=106.8$ 108.3). Officers (commissioned and warrant officers) made up $15.7 \%$ of activated RC soldiers and accounted for $4.3 \%$ of attempters $(n=47)$, with an overall rate of $26 / 100,000$ person-years $(95 \% \mathrm{CI}=25.3-26.1)$. The overall suicide attempt rate for activated RC enlisted soldiers was more than four times higher than the rate for officers (rate ratio $=4.2[95 \% \mathrm{CI}=3.1-5.6])$.

\section{Socio-demographic characteristics}

Among enlisted RC soldiers, females were more than twice as likely as males to have a documented suicide attempt. Those younger than 21 years had the highest odds of suicide attempt ( $\mathrm{OR}=3.9[95 \% \mathrm{CI}=3.0-5.1])$, with odds decreasing monotonically as age increased. Odds were also elevated among those who were less than high school-educated ( $\mathrm{OR}=1.2[95 \% \mathrm{CI}=1.1-1.4]$ ), currently married $(\mathrm{OR}=1.5[95 \% \mathrm{CI}=1.3-1.8])$, and 25 years or older when they entered the Army $(\mathrm{OR}=1.3$ $[95 \% \mathrm{CI}=1.0-1.6])$. Odds of suicide attempt were lower among soldiers who were Black or Asian $(\mathrm{ORs}=0.5-$ $0.8), 40$ years or older $(\mathrm{OR}=0.6$ [95\% CI: $0.5-0.8])$, college-educated $(\mathrm{OR}=0.6 \quad[95 \% \mathrm{CI}=0.4-0.8])$, and younger than 21 when they entered the Army $(\mathrm{OR}=0.6$ [95\% CI $=0.5-0.7])$. Standardized risk of suicide attempt was highest for enlisted RC soldiers who were younger than 21 ( $\mathrm{SRE}=293 / 100,000$ person-years), female $(\mathrm{SRE}=221 / 100,000$ person-years), and 25 years or older when they entered the Army $(S R E=203 / 100,000$ person-years) (Table 1). The only socio-demographic variable associated with suicide attempt among officers was gender, with odds being more than three times higher among females $(\mathrm{OR}=3.3 \quad[95 \% \mathrm{CI}=1.7-6.1])$ (Table 2). Female gender was also the socio-demographic category with highest standardized risk in the officer population $(\mathrm{SRE}=61 / 100,000$ person-years $)$.

\section{Active time in service}

Adjusting for socio-demographic variables, enlisted RC soldiers in their first two active years of service had higher odds of suicide attempt relative to those with 510 active years of service ( $\mathrm{OR}=1.9[95 \% \mathrm{CI}=1.4-2.5]$ ), whereas those with more than 10 active years of service had lower odds $(\mathrm{OR}=0.7[95 \% \mathrm{CI}=0.5-1.0])$ (Table 3). Subsequent pairwise analysis found that the ORs for 12 years (0-24 months) and 3-4 years (25-48 months) of service also differed $\left(\chi^{2}{ }_{1}=17.5, p<0.0001\right)$. The standardized risk for enlisted RC personnel with 1-2 years of service (SRE $=160 / 100,000$ person-years) was nearly three times higher than for those with more than 10 years of service (SRE $=55 / 100,000$ person-years) (Table 3). Time in service was not associated with suicide attempt among officers (Table 4).

A discrete-time survival model (Fig. 1) demonstrated greatly elevated risk among enlisted soldiers during their first 6 active months in the Army, with risk of suicide attempt ranging from 18 to $32 / 100,000$ person-months and peaking in the 2 nd active month of service. From the 7th through the 18th active month of service, risk generally ranged from 10 to $15 / 100,000$ person-months, followed by a decrease to approximately $5-10 / 100,000$ person-months through the 36th active month of service. Monthly risk 
Table 1 Multivariable associations of socio-demographic characteristics with suicide attempt among activated enlisted soldiers in the U.S. Army reserve components ${ }^{\mathrm{a}}$

\begin{tabular}{|c|c|c|c|c|c|c|c|}
\hline & OR & $(95 \% \mathrm{Cl})$ & Cases $(N)$ & Total $(N)^{b}$ & Rate $^{c}$ & Pop $\%^{d}$ & $\mathrm{SRE}^{\mathrm{e}}$ \\
\hline \multicolumn{8}{|l|}{ Gender } \\
\hline Male & 1.0 & - & 713 & $9,951,713$ & 86 & 84.5 & 86 \\
\hline Female & $2.6^{*}$ & $(2.2-2.9)$ & 343 & $1,828,343$ & 225 & 15.5 & 221 \\
\hline$x^{2}{ }_{1}$ & $188.4^{*}$ & & & & & & \\
\hline \multicolumn{8}{|c|}{ Age at Army Entry (years) } \\
\hline$<21$ & $0.6^{*}$ & $(0.5-0.7)$ & 748 & $8,657,748$ & 104 & 73.5 & 93 \\
\hline $21-24$ & 1.0 & - & 189 & $1,937,989$ & 117 & 16.4 & 157 \\
\hline$\geq 25$ & $1.3^{*}$ & $(1.0-1.6)$ & 119 & $1,184,319$ & 121 & 10.1 & 203 \\
\hline$x_{2}^{2}$ & $60.7^{*}$ & & & & & & \\
\hline \multicolumn{8}{|l|}{ Current Age (years) } \\
\hline$<21$ & $3.9^{*}$ & $(3.0-5.1)$ & 354 & $1,805,754$ & 235 & 15.3 & 293 \\
\hline $21-24$ & $1.9^{*}$ & $(1.4-2.4)$ & 225 & $2,180,025$ & 124 & 18.5 & 137 \\
\hline $25-29$ & $1.4^{*}$ & $(1.1-1.8)$ & 184 & $1,969,584$ & 112 & 16.7 & 105 \\
\hline $30-34$ & 1.0 & - & 101 & $1,458,301$ & 83 & 12.4 & 73 \\
\hline $35-39$ & 0.8 & $(0.6-1.1)$ & 85 & $1,622,885$ & 63 & 13.8 & 59 \\
\hline$\geq 40$ & $0.6^{*}$ & $(0.5-0.8)$ & 107 & $2,743,507$ & 47 & 23.3 & 45 \\
\hline$x^{2}{ }_{5}$ & $220.1^{*}$ & & & & & & \\
\hline \multicolumn{8}{|l|}{ Race/Ethnicity } \\
\hline White & 1.0 & - & 752 & $7,954,552$ & 113 & 67.5 & 116 \\
\hline Black & $0.8^{*}$ & $(0.7-1.0)$ & 163 & $2,065,363$ & 95 & 17.5 & 93 \\
\hline Hispanic & 0.8 & $(0.7-1.0)$ & 98 & $1,144,298$ & 103 & 9.7 & 97 \\
\hline Asian & $0.5^{*}$ & $(0.3-0.7)$ & 19 & 403,819 & 57 & 3.4 & 53 \\
\hline Other & 1.2 & $(0.8-1.8)$ & 24 & 212,024 & 136 & 1.8 & 136 \\
\hline$x^{2}{ }_{4}$ & $18.8^{*}$ & & & & & & \\
\hline \multicolumn{8}{|l|}{ Education } \\
\hline$<$ High School $^{f}$ & $1.2^{*}$ & $(1.1-1.4)$ & 276 & $1,832,476$ & 181 & 15.6 & 132 \\
\hline High School & 1.0 & - & 688 & $7,961,288$ & 104 & 67.6 & 106 \\
\hline Some College & 0.9 & $(0.6-1.2)$ & 42 & 706,842 & 71 & 6.0 & 93 \\
\hline$\geq$ College & $0.6^{*}$ & $(0.4-0.8)$ & 50 & $1,279,450$ & 47 & 10.9 & 63 \\
\hline$x^{2}$ & $20.3^{*}$ & & & & & & \\
\hline \multicolumn{8}{|l|}{ Marital Status } \\
\hline Never Married & 1.0 & - & 620 & $5,846,020$ & 127 & 49.6 & 92 \\
\hline Currently Married & $1.5^{*}$ & $(1.3-1.8)$ & 397 & $5,392,597$ & 88 & 45.8 & 142 \\
\hline Previously Married & 1.4 & $(1.0-2.0)$ & 39 & 541,439 & 86 & 4.6 & 132 \\
\hline$x_{2}^{2}$ & $29.8^{*}$ & & & & & & \\
\hline Total & - & - & 1056 & $11,780,056$ & 108 & 100.0 & - \\
\hline
\end{tabular}

${ }^{a}$ The sample of activated Reserve Component enlisted soldiers ( $n=1056$ cases, 58,895 control person-months) is a subset of the total Reserve Component sample ( $n=70,970$ person-months) from the Army STARRS Historical Administrative Data Study (HADS). All control person-months were assigned a weight of 200 to adjust for under-sampling. The analysis included a dummy predictor variable for calendar month and year to control for secular trends

${ }^{\mathrm{b}}$ Total includes both cases (i.e., suicide attempters) and weighted control person-months

'Rate per 100,000 person-years, calculated based on $n_{1} / n_{2}$, where $n_{1}$ is the unique number of soldiers within each category and $n_{2}$ is the annual number of person-years, not person-months, in the population

${ }^{\mathrm{d}}$ Pop \% Percentage of the activated Reserve Component enlisted population

e SRE Standardized risk estimate (suicide attempters per 100,000 person-years) was calculated assuming other predictors were at their sample-wide means $\mathrm{f}_{<}$- High School includes: General Educational Development credential (GED), home study diploma, occupational program certificate, correspondence school diploma, high school certificate of attendance, adult education diploma, and other non-traditional high school credentials ${ }^{*} p<0.05$ 
Table 2 Multivariable associations of socio-demographic characteristics with suicide attempt among activated officers in the U.S. Army reserve components ${ }^{\mathrm{a}}$

\begin{tabular}{|c|c|c|c|c|c|c|c|}
\hline & OR & $(95 \% \mathrm{Cl})$ & Cases $(N)$ & Total $(N)^{b}$ & Rate $^{c}$ & Pop $\%^{d}$ & $\mathrm{SRE}^{\mathrm{e}}$ \\
\hline \multicolumn{8}{|l|}{ Gender } \\
\hline Male & 1.0 & - & 30 & $1,858,430$ & 19 & 84.7 & 19 \\
\hline Female & $3.3^{*}$ & $(1.7-6.1)$ & 17 & 336,017 & 61 & 15.3 & 61 \\
\hline$x^{2}$ & $13.7^{*}$ & & & & & & \\
\hline \multicolumn{8}{|l|}{ Age at Army Entry (years) } \\
\hline$<21$ & 0.9 & $(0.5-1.8)$ & 22 & $1,158,822$ & 23 & 52.8 & 24 \\
\hline $21-24$ & 1.0 & - & 15 & 694,415 & 26 & 31.6 & 25 \\
\hline$\geq 25$ & 1.3 & $(0.6-3.0)$ & 10 & 341,210 & 35 & 15.5 & 34 \\
\hline$x_{2}^{2}$ & 0.8 & & & & & & \\
\hline \multicolumn{8}{|l|}{ Current Age (years) } \\
\hline$\leq 29$ & 0.7 & $(0.3-2.0)$ & 7 & 231,407 & 36 & 10.5 & 38 \\
\hline $30-34$ & 1.0 & - & 10 & 280,610 & 43 & 12.8 & 46 \\
\hline $35-39$ & 0.4 & $(0.2-1.1)$ & 8 & 486,008 & 20 & 22.1 & 21 \\
\hline$\geq 40$ & $0.4^{*}$ & $(0.2-0.9)$ & 22 & $1,196,422$ & 22 & 54.5 & 21 \\
\hline$x^{2}{ }_{3}$ & 5.7 & & & & & & \\
\hline \multicolumn{8}{|l|}{ Race/Ethnicity } \\
\hline White & 1.0 & - & 38 & $1,688,438$ & 27 & 76.9 & 29 \\
\hline Non-White & 0.6 & $(0.3-1.3)$ & 9 & 506,009 & 21 & 23.1 & 18 \\
\hline$x_{1}^{2}$ & 1.5 & & & & & & \\
\hline \multicolumn{8}{|l|}{ Education } \\
\hline$\leq$ College & 1.0 & - & 31 & $1,511,631$ & 25 & 68.9 & 24 \\
\hline > College & 1.2 & $(0.7-2.4)$ & 16 & 682,816 & 28 & 31.1 & 30 \\
\hline$x^{2}{ }_{1}$ & 0.5 & & & & & & \\
\hline \multicolumn{8}{|l|}{ Marital Status } \\
\hline Never/Previously Married & 1.0 & - & 19 & 676,219 & 34 & 30.8 & 28 \\
\hline Currently Married & 0.9 & $(0.5-1.6)$ & 28 & $1,518,228$ & 22 & 69.2 & 24 \\
\hline$x^{2}{ }_{1}$ & 0.2 & & & & & & \\
\hline Total & & & 47 & $2,194,447$ & 26 & 100.0 & - \\
\hline
\end{tabular}

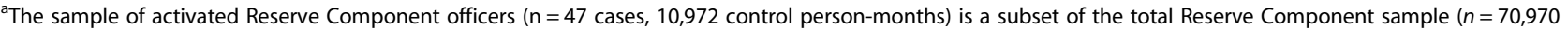
person-months) from the Army STARRS Historical Administrative Data Study (HADS). All control person-months were assigned a weight of 200 to adjust for undersampling. The analysis included a dummy predictor variable for calendar month and year to control for secular trends

${ }^{\mathrm{b}}$ Total includes both cases (i.e., suicide attempters) and weighted control person-months

'Rate per 100,000 person-years, calculated based on $n_{1} / n_{2}$, where $n_{1}$ is the unique number of soldiers within each category and $n_{2}$ is the annual number of person-years, not person-months, in the population

${ }^{\mathrm{d}}$ Pop \% Percentage of the activated Reserve Component officer population

${ }^{\text {e}}$ SRE Standardized risk estimate (suicide attempters per 100,000 person-years) was calculated assuming other predictors were at their sample-wide means ${ }^{*} p<0.05$

was not examined among officers due to the small number of cases.

\section{Deployment status}

We found higher odds of suicide attempt among previously deployed $\mathrm{RC}$ enlisted soldiers compared to those currently deployed (OR = 1.3 [95\% CI: 1.1-1.6]), adjusting for socio-demographic variables (Table 3). Although the OR for never deployed was nonsignificant, a subsequent pairwise analysis found no difference between never deployed and previously deployed $\left(\chi^{2}{ }_{1}=1.7, p=0.20\right)$.
Standardized risk was highest for enlisted RC soldiers who were previously deployed (SRE $=129 / 100,000$ personyears) and lowest for those currently deployed (SRE $=93$ / 100,000 person-years). Deployment status was not associated with suicide attempt among RC officers (Table 4).

\section{Mental health diagnosis}

Among those who attempted suicide, $45.1 \%$ of RC enlisted soldiers and $63.8 \%$ of officers had a previous mental health diagnosis. Among attempters with a history of mental health diagnosis, $69.3 \%$ of enlisted soldiers and 
Table 3 Multivariable associations of active time in service, deployment status, and time since most recent mental health diagnosis with suicide attempt among activated enlisted soldiers in the U.S. Army reserve components ${ }^{a, b}$

\begin{tabular}{|c|c|c|c|c|c|c|c|}
\hline & OR & $(95 \% \mathrm{Cl})$ & Cases $(N)$ & Total $(N)^{c}$ & Rate $^{d}$ & Pop \%e & $\mathrm{SRE}^{f}$ \\
\hline \multicolumn{8}{|c|}{ I. Active Time in Service ${ }^{b, g}$} \\
\hline $1-2$ years & $1.9^{*}$ & $(1.4-2.5)$ & 651 & $4,043,051$ & 193 & 34.3 & 160 \\
\hline $3-4$ years & 1.1 & $(0.9-1.5)$ & 111 & $1,441,711$ & 92 & 12.2 & 96 \\
\hline $5-10$ years & 1.0 & - & 126 & $1,873,726$ & 81 & 15.9 & 84 \\
\hline$>10$ years & $0.7^{*}$ & $(0.5-1.0)$ & 168 & $4,421,568$ & 46 & 37.5 & 55 \\
\hline$x^{2}$ & $32.0^{*}$ & & & & & & \\
\hline \multicolumn{8}{|l|}{ II. Deployment Status ${ }^{\text {b }}$} \\
\hline Never deployed & 1.2 & $(1.0-1.4)$ & 634 & $5,864,234$ & 130 & 49.8 & 108 \\
\hline Currently deployed & 1.0 & - & 230 & $3,393,630$ & 81 & 28.8 & 93 \\
\hline Previously deployed & $1.3^{*}$ & $(1.1-1.6)$ & 192 & $2,522,192$ & 91 & 21.4 & 129 \\
\hline$x_{2}^{2}$ & $7.4^{*}$ & & & & & & \\
\hline \multicolumn{8}{|c|}{ III. Time Since Most Recent Mental Health Diagnosis ${ }^{b}$} \\
\hline No Diagnosis & 1.0 & - & 580 & $10,198,180$ & 68 & 86.6 & 65 \\
\hline 1 Month & $28.4^{*}$ & $(24.7-32.7)$ & 330 & 254,530 & 1556 & 2.2 & 1863 \\
\hline 2-3 Months & $6.0^{*}$ & $(4.6-7.8)$ & 61 & 217,661 & 336 & 1.8 & 399 \\
\hline 4-12 Months & $2.8^{*}$ & $(2.1-3.7)$ & 52 & 438,652 & 142 & 3.7 & 184 \\
\hline$\geq 13$ Months & $1.5^{*}$ & $(1.0-2.1)$ & 33 & 671,033 & 59 & 5.7 & 101 \\
\hline$x_{4}^{2}$ & 2215.1 & & & & & & \\
\hline $\begin{array}{l}{ }^{a} \text { The sample of activat } \\
\text { ( } n=70,970 \text { person-mo } \\
\text { adjust for under-sampl } \\
{ }^{\mathrm{b}} \text { Time in service, deplo } \\
\text { (gender, age at entry i } \\
\text { year to control for sect } \\
{ }^{c} \text { Total includes both ca } \\
{ }^{\mathrm{d}} \text { Rate per } 100,000 \text { pers } \\
\text { person-years, not persc } \\
{ }^{\mathrm{e}} \text { Pop \% Percentage of } \\
{ }^{\mathrm{f}} \text { SRE Standardized risk } \\
{ }^{\mathrm{g}} \text { Based on the number } \\
{ }^{*} p<0.05\end{array}$ & $\begin{array}{l}\text { e Comp } \\
\text { the Arr } \\
\text { atus, and } \\
\text { rmy, curr } \\
\text { s } \\
\text { uicide at } \\
\text { calculat } \\
\text {, in the } \\
\text { ted Rese } \\
\text { suicide } \\
\text { is a sold }\end{array}$ & $\begin{array}{l}\text { sted soldiers ( } \\
S \text { Historical Ad } \\
\text { ealth diagnos } \\
\text { race, educatio } \\
\text { and weighte } \\
\text { on } n_{1} / n_{2} \text {, whe } \\
n \\
\text { Donent enliste } \\
\text { s per } 100,000 \\
\text { on active dut }\end{array}$ & $\begin{array}{l}\text { cases, } 58,895 \\
\text { ve Data Stu } \\
\text { ach examine } \\
\text { status). All a } \\
\text { person-mon } \\
\text { e unique nu } \\
\text { ion } \\
2 \text { years) was cal } \\
2 \text { years }\end{array}$ & $\begin{array}{l}\text { All control p } \\
\text { arate model } \\
\text { so included a } \\
\text { oldiers within } \\
\text { suming other } \\
\text { of active ser }\end{array}$ & $\begin{array}{l}\text { ths wer } \\
\text { red for } \\
\text { redictor } \\
\text { gory an } \\
\text { were a } \\
\text { ears }=2\end{array}$ & $\begin{array}{l}\text { d a weight } \\
\text { io-demogra } \\
\text { or calenda } \\
\text { annual n } \\
\text { ths of activ }\end{array}$ & $\begin{array}{l}\text { ample } \\
\text { ables } \\
\text { and } \\
\text { etc.) }\end{array}$ \\
\hline
\end{tabular}

$56.7 \%$ of officers most recently had a diagnosis recorded in the month prior to attempting suicide. Adjusting for socio-demographics, enlisted soldiers with a mental health diagnosis in the previous month had the highest odds of attempt compared to those without a diagnosis $(\mathrm{OR}=28.4$ [95\% CI $=24.7-32.7]$ ), with odds decreasing monotonically as time since most recent diagnosis increased from 2 to 3 months $(\mathrm{OR}=6.0[95 \% \mathrm{CI}=4.6-7.8])$ to 13 months or more $(\mathrm{OR}=1.5[95 \% \mathrm{CI}=1.0-2.1])$ (Table 3). Pairwise analyses found that the differences between those levels were significant (ranging from $X^{2}{ }_{1}=4.8-173.1, p<0.0001-$ 0.027). Standardized risk was highest at one month since most recent diagnosis (SRE $=1863 / 100,000$ person-years), substantially lower at $2-3$ months since diagnosis $(\mathrm{SRE}=$ 399/100,000 person-years), and lowest for RC enlisted soldiers with no history of diagnosis (SRE $=65 / 100,000$ person-years). Officers with a mental health diagnosis in the previous month similarly had the highest odds of suicide attempt $(\mathrm{OR}=49.6[95 \% \mathrm{CI}=24.3-100.9])$, with odds decreasing as time since most recent diagnosis increased from 2 to 3 months $(\mathrm{OR}=16.4[95 \% \mathrm{CI}=6.2-43.3])$ to 4 months or more $(\mathrm{OR}=3.1[95 \% \mathrm{CI}=1.3-7.7])$ (Table 4). Pairwise analyses found that the differences between all other levels of the variable were significant (ranging from $\left.X_{1}^{2}=6.2-32.0, p<0.0001-0.013\right)$. The standardized risk among officers decreased from 540/100,000 person-years at 1 month since diagnosis to $38 / 100,000$ person-years at 4 or more months since diagnosis, with never-diagnosed officers having a standardized risk of $11 / 100,000$ person-years.

\section{Discussion}

By combining multiple administrative data systems, the current study presents the most comprehensive analysis to date of documented suicide attempts among activated $\mathrm{RC}$ soldiers during the wars in Iraq and Afghanistan. It complements previous $\mathrm{RC}$ research on suicide death [33-35] and ideation (e.g., [15-17]). The findings reveal 
Table 4 Multivariable associations of active time in service, deployment status, and time since most recent mental health diagnosis with suicide attempt among activated officers in the U.S. Army reserve components ${ }^{a, b}$

\begin{tabular}{|c|c|c|c|c|c|c|c|}
\hline & OR & $(95 \% \mathrm{Cl})$ & Cases $(N)$ & Total $(N)^{c}$ & Rate $^{d}$ & Pop \% ${ }^{\mathrm{e}}$ & $\mathrm{SRE}^{\mathrm{f}}$ \\
\hline \multicolumn{8}{|c|}{ I. Active Time in Service $\mathrm{e}^{\mathrm{b}, \mathrm{g}}$} \\
\hline $1-4$ years & 1.1 & $(0.4-3.1)$ & 9 & 255,609 & 42 & 11.6 & 34 \\
\hline $5-10$ years & 1.0 & - & 10 & 330,010 & 36 & 15.0 & 28 \\
\hline$>10$ years & 1.0 & $(0.4-2.6)$ & 28 & $1,608,828$ & 21 & 73.3 & 23 \\
\hline$x_{2}^{2}$ & 0.1 & & & & & & \\
\hline \multicolumn{8}{|l|}{ II. Deployment Status ${ }^{\text {b }}$} \\
\hline Never deployed & 0.9 & $(0.4-1.8)$ & 23 & $1,014,623$ & 27 & 46.2 & 29 \\
\hline Currently deployed & 1.0 & - & 12 & 517,412 & 28 & 23.6 & 25 \\
\hline Previously deployed & 0.7 & $(0.3-1.6)$ & 12 & 662,412 & 22 & 30.2 & 24 \\
\hline$x_{2}^{2}$ & 0.7 & & & & & & \\
\hline \multicolumn{8}{|c|}{ III. Time Since Most Recent Mental Health Diagnosis ${ }^{\mathrm{b}}$} \\
\hline No Diagnosis & 1.0 & - & 17 & $1,881,817$ & 11 & 85.8 & 11 \\
\hline 1 Month & $49.6^{*}$ & $(24.3-100.9)$ & 17 & 39,817 & 512 & 1.8 & 540 \\
\hline 2-3 Months & $16.4^{*}$ & $(6.2-43.3)$ & 6 & 37,206 & 194 & 1.7 & 189 \\
\hline$\geq 4$ Months & $3.1^{*}$ & $(1.3-7.7)$ & 7 & 235,607 & 36 & 10.7 & 38 \\
\hline$x_{3}^{2}$ & $124.3^{*}$ & & & & & & \\
\hline
\end{tabular}

${ }^{a}$ The sample of activated Reserve Component officers ( $n=47$ cases, 10,972 control person-months) is a subset of the total Reserve Component sample ( $n=70,970$ person-months) from the Army STARRS Historical Administrative Data Study (HADS). All control person-months were assigned a weight of 200 to adjust for under-sampling

${ }^{\mathrm{b}}$ Time in service, deployment status, and mental health diagnosis were each examined in a separate model that controlled for basic socio-demographic variables (gender, age at entry into the Army, current age, race, education, marital status). All analyses also included a dummy predictor variable for calendar month and year to control for secular trends

'Total includes both cases (i.e., suicide attempters) and weighted control person-months

${ }^{d}$ Rate per 100,000 person-years, calculated based on $n_{1} / n_{2}$, where $n_{1}$ is the unique number of soldiers within each category and $n_{2}$ is the annual number of person-years, not person-months, in the population

${ }^{\mathrm{e}}$ Pop \% Percentage of the activated Reserve Component officer population

${ }^{f} S R E$ Standardized risk estimate (suicide attempters per 100,000 person-years) was calculated assuming other predictors were at their sample-wide means ${ }^{g}$ Based on the number of months a soldier served on active duty (e.g., $1-4$ years $=0-48$ months of active service; $5-10$ years $=60-120$ months of active service, etc.)

${ }^{*} p<0.05$

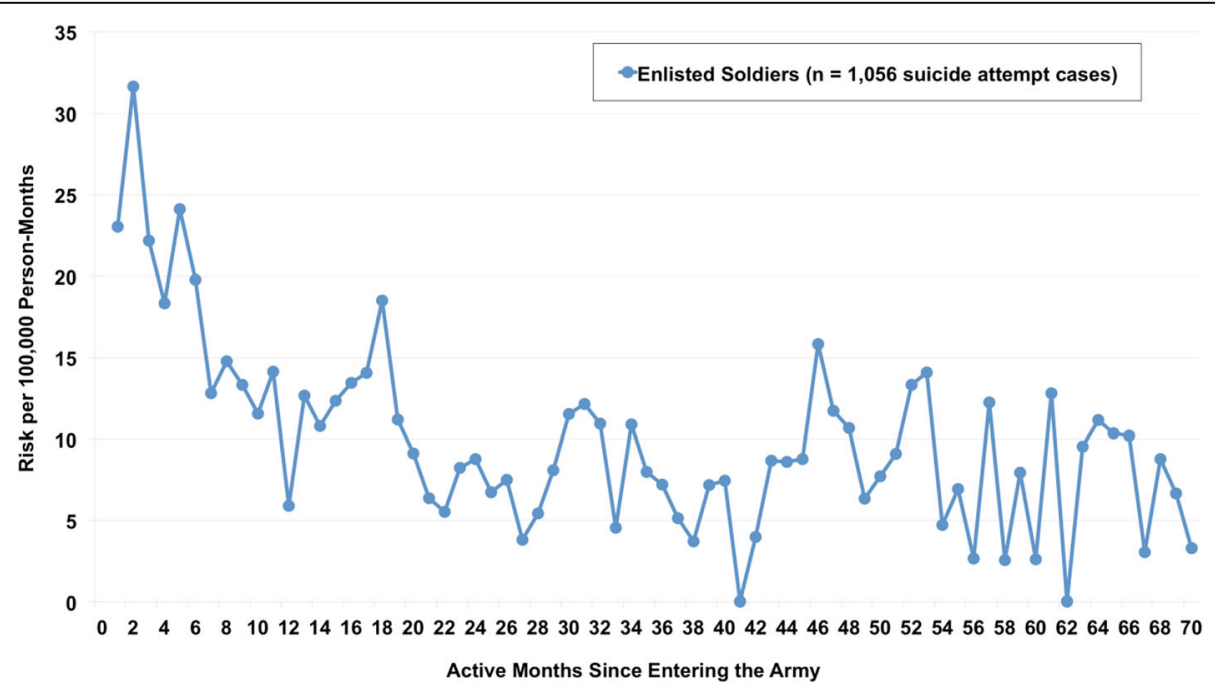

Fig. 1 Risk of Suicide Attempt among Activated Reserve Component Enlisted Soldiers by Active Months Since Entering the Army. 
enlisted soldiers account for the vast majority of RC suicide attempts documented during active duty, with an overall rate more than four times higher than the rate for officers. This rank-based discrepancy in risk was also observed among $\mathrm{AC}$ soldiers [8]. Interestingly, while the rates for $\mathrm{RC}$ and $\mathrm{AC}$ officers are comparable, the rate for $\mathrm{RC}$ enlisted soldiers is far lower than the published rate of 377 per 100,000 person-years for AC enlisted soldiers [8]. Previous surveys have found mixed results when comparing $\mathrm{RC}$ and $\mathrm{AC}$ soldiers on prevalence of suicide ideation and attempts [11, 12, 36]. The lower RC attempt rate in the current study may be attributable to their more limited time on active duty (when suicide attempts are captured by administrative records) relative to AC soldiers. It is also possible that RC soldiers with suicidal thoughts or other mental health symptoms that increase suicide attempt risk are less likely to be activated or remain on active duty for extended periods of time.

Among RC enlisted soldiers, the positive associations of suicide attempt with being female, younger, non-Hispanic white, less educated, and older when entering the Army are consistent with findings from the $\mathrm{AC}$ enlisted population, as are the higher odds among enlisted personnel who were in their first two years of service, previously deployed, and recently diagnosed with a mental health disorder [8]. Of particular note, $\mathrm{RC}$ and AC enlisted soldiers have a similar pattern of monthly suicide attempt risk after entering service [8], with peak risk occurring toward the end of basic training followed by a sharp decline.

Beyond potential differences in the overall attempted suicide rate among activated RC vs. AC enlisted soldiers, our findings indicate two noteworthy differences in predictor variables. First, whereas the multivariable association of marital status with suicide attempt was nonsignificant in the AC enlisted population [8], currently married $\mathrm{RC}$ soldiers were significantly more likely to attempt suicide than those who were never married. Interestingly, previous univariable analyses found that never married RC enlisted soldiers had higher odds of suicide attempt [9] - a finding that is consistent with the higher crude rate among never married RC soldiers in the current study indicating that other variables in the adjusted model are influencing the association of marital status. Second, whereas being never deployed had a robust positive association with suicide attempt among AC enlisted soldiers $[7,8]$, it was nonsignificant among RC enlisted soldiers in adjusted models despite having the highest crude rate. The reason for this discrepancy between $\mathrm{RC}$ and AC soldiers is not yet known but may be attributable to differences in socio-demographic and occupational composition (e.g., the U.S. Army Reserve does not have combat units). A more detailed analysis of risk by deployment status [7] and military occupation [37] may improve understanding of how the association of deployment status with suicide attempts may differ between the RCs and $\mathrm{AC}$.

Previous work found few predictors of suicide attempt among AC officers [8]. Even fewer predictors were identified in this analysis of RC officers, with female gender and recent mental health diagnosis being the only significant variables. However, with only 47 suicide attempt cases, power to detect significant associations among RC officers was limited. We plan to address this limitation in the follow-up study to Army STARRS (STARRS-LS for "longitudinal study"), which will include additional administrative data beyond the original 2004-2009 time period, allowing more officer suicide attempt cases to be captured and increased statistical power.

Several limitations in the current study are noteworthy. First, administratively recorded suicide attempts are limited to events captured by the healthcare system. These records are subject to errors in coding and clinical judgment, as well as changes in policy and procedures. Second, the data are limited to person-months during which individual RC soldiers were federally activated. Consequently, these records do not include suicide attempts or mental health diagnoses that occurred while soldiers were inactive, and time in service should not be interpreted as continuous (e.g., 12 months of active service may not correspond to 12 consecutive calendar months). Third, findings represent activated RC soldiers during 2004-2009 and may not generalize to other time periods or populations. Fourth, deployment and Army attrition are non-random events [38-40], which influences the composition of groups defined by those variables. Therefore, differences based on deployment status and active time in service should not be interpreted as within-person changes over time. For example, it is possible for soldiers who are currently deployed to have also been previously deployed. This means the currently deployed group includes soldiers on their first deployment as well as soldiers on their second deployment, third deployment, etc. Those on their first deployment are likely to have the highest risk of adverse outcomes (which could preclude subsequent deployments), whereas those on their second or third deployment are likely to be more resilient soldiers who were purposefully selected to deploy multiple times (often referred to as the "healthy warrior effect").

\section{Conclusions}

With the limitations in mind, the findings indicate that enlisted soldiers in their first two years of active service account for the majority of suicide attempts in the RC population, and soldiers with a recently documented mental health diagnosis are at substantially elevated risk. 
Although predictors are largely consistent with those found in the AC [8], there were some notable differences (e.g., marital status, deployment status). Most significantly, the intermittent nature of RC service creates unique challenges for risk assessment and intervention that are not present in the full-time AC population. AC soldiers in garrison have military healthcare access and can be closely monitored by leaders and clinicians. In contrast, deactivated members of the RCs do not have access to the military healthcare system, and they return to communities that are widely dispersed, often rural, and potentially remote, presenting obstacles to mental health screening and treatment [41]. Addressing these challenges may require new programs, such as peer-topeer support [42], that can reach RC soldiers in their local communities.

\section{Additional file}

Additional file 1: Supplemental Information Tables. Contains additional methodological information. (DOCX $26 \mathrm{~kb}$ )

\begin{abstract}
Abbreviations
AC: Active Component; Cl: Confidence interval; CTS: Contingency Tracking System; DMDC: Defense Manpower Data Center; DOD: Department of Defense; DODSER: Department of Defense Suicide Event Report; HADS: Historical Administrative Data Study; ICD-9-CM: International Classification of Diseases, Ninth Revision-Clinical Modification; MDR: Military Health System Data Repository; NIH: National Institutes of Health; NIMH: National Institute of Mental Health; OR: Odds ratio; Pop \%: Percentage of the population; RC: Reserve Component; SAS: Statistical Analysis System; SRE: Standardized risk estimate; STARRS: Study to Assess Risk and Resilience in Servicemembers; STARRS-LS: Study to Assess Risk and Resilience in Servicemembers-Longitudinal Study; TMDS: Theater Medical Data Store; TRAC2ES: Transportation Command Regulating And Command And Control Evacuation System; US: United States; VA: Veterans Affairs
\end{abstract}

\section{Acknowledgments}

The Army STARRS Team consists of Co-Principal Investigators: Robert J. Ursano, MD (Uniformed Services University of the Health Sciences) and Murray B. Stein, MD, MPH (University of California San Diego and VA San Diego Healthcare System).

Site Principal Investigators: Steven Heeringa, PhD (University of Michigan), James Wagner, PhD (University of Michigan) and Ronald C. Kessler, PhD (Harvard Medical School).

Army liaison/consultant: Kenneth Cox, MD, MPH (US Army Public Health Center).

Other team members: Pablo A. Aliaga, MS (Uniformed Services University of the Health Sciences); COL David M. Benedek, MD (Uniformed Services University of the Health Sciences); Laura Campbell-Sills, PhD (University of California San Diego): Carol S. Fullerton, PhD (Uniformed Services University of the Health Sciences); Nancy Gebler, MA (University of Michigan); Robert K. Gifford, PhD (Uniformed Services University of the Health Sciences); Paul E. Hurwitz, MPH (Uniformed Services University of the Health Sciences); Sonia Jain, PhD (University of California San Diego): Tzu-Cheg Kao, PhD (Uniformed Services University of the Health Sciences); Lisa Lewandowski-Romps, PhD (University of Michigan); Holly Herberman Mash, PhD (Uniformed Services University of the Health Sciences); James E. McCarroll, PhD, MPH (Uniformed Services University of the Health Sciences); James A. Naifeh, PhD (Uniformed Services University of the Health Sciences); Tsz Hin Hinz Ng, MPH (Uniformed Services University of the Health Sciences); Matthew K. Nock, PhD (Harvard University); Nancy A. Sampson, BA (Harvard Medical School); CDR Patcho Santiago, MD, MPH (Uniformed Services University of the Health Sciences);
LTC Gary H. Wynn, MD (Uniformed Services University of the Health Sciences); and Alan M. Zaslavsky, PhD (Harvard Medical School).

\section{Funding}

Army STARRS was sponsored by the Department of the Army and funded under cooperative agreement number U01MH087981 (2009-2015) with the U.S. Department of Health and Human Services, National Institutes of Health, National Institute of Mental Health (NIH/NIMH). Subsequently, STARRS-LS was sponsored and funded by the Department of Defense (USUHS grant number HU0001-15-2-0004).

As part of the Army STARRS cooperative agreement, scientists employed by $\mathrm{NIMH}$ (Colpe and Schoenbaum) and Army liaisons/consultants (COL Steven Cersovsky, MD, MPH USAPHC and Kenneth Cox, MD, MPH USAPHC) collaborated to develop the study protocol and data collection instruments, supervise data collection, interpret results, and prepare reports. Although a draft of this manuscript was submitted to the Army and NIMH for review and comment prior to submission, this was with the understanding that comments would be no more than advisory. Under STARRS-LS, the role of the Department of Defense does not extend beyond the sponsorship and funding of this research.

The contents are solely the responsibility of the authors and do not necessarily represent the views of the Department of Health and Human Services, NIMH, or the Department of the Army, or the Department of Defense.

\section{Availability of data and materials}

For information on data availability, please contact the Uniformed Services University of the Health Sciences Institutional Review Board, 4301 Jones Bridge Road, Bethesda, MD 20814.

\section{Authors' contributions}

CSF, HBHM, JAN, MBS, RCK, and RJU contributed to the study concept and design. CARD, CSF, GHW, HBHM, HMD, JAN, MBS, NAS, OIG, RCK, RJU, THHN, and TK were responsible for the acquisition, analysis, or interpretation of the data. CARD, CSF, HBHM, JAN, OIG, RCK, and RJU were involved in drafting the manuscript. CARD, CSF, GHW, HMD, HBHM, JAN, MBS, NAS, OIG, RCK, RJU, THHN, and TK contributed to critical revision of the manuscript for important intellectual content. CARD, CSF, GHW, HBHM, HMD, JAN, MBS, NAS, OIG, RCK, RJU, THHN, and TK provided administrative, technical, and material support. All authors read and approved the final manuscript.

\section{Ethics approval and consent to participate}

This component of Army STARRS was approved by the Institutional Review Boards of the Uniformed Services University of the Health Sciences for the Henry M. Jackson Foundation (the primary grantee), the University of Michigan Institute for Social Research (site of the Army STARRS Data Enclave), University of California, San Diego, and Harvard Medical School, which determined that the present study did not constitute human participant research because it relies entirely on deidentified secondary data.

\section{Consent for publication}

Not applicable.

\section{Competing interests}

MBS has been a consultant for Care Management Technologies, received payment for his editorial work from UpToDate and Depression and Anxiety, and had research support for pharmacological imaging studies from Janssen. In the past 3 years, RCK received support for his epidemiological studies from Sanofi Aventis; was a consultant for Johnson \& Johnson Wellness and Prevention, Shire, Takeda; and served on an advisory board for the Johnson \& Johnson Services Inc. Lake Nona Life Project. RCK is a coowner of DataStat, Inc., a market research firm that carries out healthcare research. The remaining authors report nothing to disclose.

\section{Publisher's Note}

Springer Nature remains neutral with regard to jurisdictional claims in published maps and institutional affiliations.

\section{Author details}

${ }^{1}$ Center for the Study of Traumatic Stress, Department of Psychiatry, Uniformed Services University of the Health Sciences, 4301 Jones Bridge 
Road, Bethesda, MD 20814, USA. ${ }^{2}$ Department of Health Care Policy, Harvard Medical School, 180 Longwood Avenue, Boston, MA 02115, USA. ${ }^{3}$ Department of Preventive Medicine and Biostatistics, Uniformed Services University of the Health Sciences, 4301 Jones Bridge Road, Bethesda, MD 20814, USA. ${ }^{4}$ Departments of Psychiatry and Family Medicine \& Public Health, University of California San Diego, 8939 Villa La Jolla Drive, Suite 200, La Jolla, CA 92037, USA. ${ }^{5}$ A San Diego Healthcare System, 8810 Rio San Diego Drive, San Diego, CA 92108, USA.

\section{Received: 27 August 2018 Accepted: 7 December 2018}

\section{Published online: 18 January 2019}

\section{References}

1. Schoenbaum M, Kessler RC, Gilman SE, Colpe LJ, Heeringa SG, Stein MB, Ursano RJ, Cox KL. Predictors of suicide and accident death in the Army study to assess risk and resilience in Servicemembers (Army STARRS). JAMA Psychiatry. 2014;71(5):493-503.

2. Black SA, Gallaway MS, Bell MR, Ritchie EC. Prevalence and risk factors associated with suicides of army soldiers 2001-2009. Mil Psychol. 2011;23(4): 433-51.

3. Ursano RJ, Kessler RC, Heeringa SG, Cox KL, Naifeh JA, Fullerton CS, Sampson NA, Kao T-C, Aliaga PA, Vegella P, et al. Nonfatal suicidal behaviors in U.S. Army administrative records, 2004-2009: results from the Army study to assess risk and resilience in Servicemembers (Army STARRS). Psychiatry. 2015;78(1):1-21.

4. Department of Veterans Affairs, Veterans health administration, Office of Mental Health and Suicide Prevention: Veteran Suicide Data Report, 20052016; September 2018.

5. Gibbons RD, Brown $\mathrm{CH}$, Hur K. Is the rate of suicide among veterans elevated? Am J Public Health. 2012;102(Supplement 1):S17-9.

6. Nock MK, Stein MB, Heeringa SG, Ursano RJ, Colpe LJ, Fullerton CS, Hwang I, Naifeh JA, Sampson NA, Schoenbaum M, et al. Prevalence and correlates of suicidal behavior among soldiers: results from the Army study to assess risk and resilience in Servicemembers (Army STARRS). JAMA Psychiatry. 2014; 71(5):514-22.

7. Ursano RJ, Kessler RC, Stein MB, Naifeh JA, Aliaga PA, Fullerton CS, Wynn $\mathrm{GH}$, Vegella PL, Ng THH, Zhang BG, et al. Risk factors, methods, and timing of suicide attempts among U.S. Army soldiers. JAMA Psychiatry. 2016;73(7): $741-9$.

8. Ursano RJ, Kessler RC, Stein MB, Naifeh JA, Aliaga PA, Fullerton CS, Sampson NA, Kao T-C, Colpe L, Schoenbaum M, et al. Suicide attempts in the U.S. Army during the wars in Afghanistan and Iraq, 2004-2009. JAMA Psychiatry. 2015;72(9):917-26.

9. Ursano RJ, Naifeh JA, Kessler RC, Gonzalez OI, Fullerton CS, Herberman Mash HB, Riggs-Donovan CA, Ng THH, Wynn GH, Dinh HM et al: Non-fatal suicidal behaviors in the administrative records of activated U.S. Army National Guard and Army Reserve soldiers, 2004-2009. Psychiatry. 2018;81(2):173-92.

10. Department of Defense: Military and Civilian Personnel by Service/Agency by State/Country. In.; 2017.

11. Ursano RJ, Heeringa SG, Stein MB, Jain S, Raman R, Sun X, Chiu WT, Colpe $\sqcup$, Fullerton CS, Gilman SE, et al. Prevalence and correlates of suicidal behavior among new soldiers in the US Army: results from the Army study to assess risk and resilience in Servicemembers (Army STARRS). Depress Anxiety. 2015;32(1):3-12.

12. Millner AJ, Ursano RJ, Hwang I, King AJ, Naifeh JA, Sampson NA, Zaslavsky AM, Stein MB, Kessler RC, Nock MK. Lifetime suicidal behaviors and career characteristics among U.S. Army soldiers: results from the Army study to assess risk and resilience in Servicemembers (Army STARRS). Suicide Life Threat Behav. 2018;48(2):230-50.

13. Lane ME, Hourani LL, Bray RM, Williams J. Prevalence of perceived stress and mental health indicators among reserve-component and active-duty military personnel. Am J Public Health. 2012;102:1213-20.

14. Rosellini AJ, Heeringa SG, Stein MB, Ursano RJ, Chiu WT, Colpe L, Fullerton CS, Gilman SE, Hwang I, Naifeh JA, et al. Lifetime prevalence of DSM-IV mental disorders among new soldiers in the U.S. Army: results from the Army study to assess risk and resilience in Servicemembers (Army STARRS). Depress Anxiety. 2015;32(1):13-24.

15. Kline A, Ciccone DS, Falca-Dodson M, Black CM, Losonczy M. Suicidal ideation among National Guard troops deployed to Iraq: the association with postdeployment readjustment problems. J Nerv Ment Dis. 2011;199: 914-20.
16. Calabrese JR, Prescott M, Tamburrino M, Liberzon I, Slembarski R, Goldmann E, Shirley E, Fine T, Goto T, Wilson K, et al. PTSD comorbidity and suicidal ideation associated with PTSD within the Ohio Army National Guard. J Clin Psychiatry. 2011;72(8):1072-8.

17. Griffith J. Suicide and war: the mediating effects of negative mood, posttraumatic stress disorder symptoms, and social support among Army National Guard soldiers. Suicide Life Threat Behav. 2012;42(4):453-69.

18. Kessler RC, Colpe L, Fullerton CS, Gebler N, Naifeh JA, Nock MK, Sampson NA, Schoenbaum M, Zaslavsky AM, Stein MB, et al. Design of the Army Study to assess risk and resilience in Servicemembers (Army STARRS). Int J Methods Psychiatr Res. 2013;22(4):267-75.

19. Willett JB, Singer JD. Investigating onset, cessation, relapse, and recovery: why you should, and how you can, use discrete-time survival analysis to examine event occurrence. J Consult Clin Psychol. 1993;61(6):952-65.

20. Schlesselman JJ. Case-control studies: design, conduct, analysis. New York, NY: Oxford University Press; 1982.

21. Gahm GA, Reger MA, Kinn JT, Luxton DD, Skopp NA, Bush NE. Addressing the surveillance goal in the National Strategy for suicide prevention: the Department of Defense Suicide Event Report. Am J Public Health. 2012; 102(Suppl 1):S24-8.

22. Walkup JT, Townsend L, Crystal S, Olfson M. A systematic review of validated methods for identifying suicide or suicidal ideation using administrative or claims data. Pharmacoepidemiol Drug Saf. 2012;21 (Suppl 1):174-82.

23. 23. SAS Institute Inc:: SAS 9.4 Software. Cary, NC: SAS Institute Inc.; 2013.

24. Segal DR, Segal MW. America's military population. Population Bulletin. 2004:59(4):1-40.

25. Lapierre CB, Schwegler AF, LaBauve BJ. Posttraumatic stress and depression symptoms in soldiers returning from combat operations in Iraq and Afghanistan. J Trauma Stress. 2007;20(6):933-43.

26. Smith TC, Ryan MAK, Wingard DL, Slymen DJ, Sallis JF, Kritz-Silverstein D. New onset and persistent symptoms of post-traumatic stress disorder self reported after deployment and combat exposures: prospective population based US military cohort study. Br Med J. 2008;336(7640):366-71.

27. Bray RM, Pemberton MR, Hourani LL, Witt M, Olmsted KLR, Brown JM, Weimer B, Lane ME, Marsden ME, Scheffler S et al: 2008 Department of Defense Survey of Health Related Behaviors Among Active Duty Military Personnel: A Component of the Defense Lifestyle Assessment Program (DLAP). In. Research Triangle Park, North Carolina: RTI International; 2009.

28. Gilman SE, Bromet EJ, Cox KL, Colpe LJ, Fullerton CS, Gruber MJ, Heeringa SG, Lewandowski-Romps L, Millikan-Bell AM, Naifeh JA, et al. Sociodemographic and career history predictors of suicide and suicide mortality in the United States Army 2004-2009. Psychol Med. 2014;44(12):2579-92.

29. Hyman J, Ireland R, Frost L, Cottrell L. Suicide incidence and risk factors in an active duty US military population. Am J Public Health. 2012;102(Suppl 1):S138-46.

30. Ursano RJ, Kessler RC, Stein MB, Naifeh JA, Nock MK, Aliaga PA, Fullerton CS, Wynn GH, Ng THH, Dinh HM, et al. Medically documented suicide ideation among U.S. Army soldiers. Suicide Life Threat Behav. 2017;47(5):612-28.

31. Roalfe AK, Holder RL, Wilson S. Standardisation of rates using logistic regression: a comparison with the direct method. BMC Health Serv Res. 2008;8:275.

32. Department of the Army: Army 2020: Generating health \& discipline in the force ahead of the strategic reset. In. Washington, DC: Department of the Army; 2012.

33. Griffith J. Suicide in the Army National Guard: an empirical inquiry. Suicide Life Threat Behav. 2012;42(1):104-19.

34. Griffith J. Correlates of suicide among Army National Guard soldiers. Mil Psychol. 2012;24:568-91.

35. Griffith J. A description of suicides in the Army National Guard during 20072014 and associated risk factors. Suicide Life Threat Behav. 2017;47(3):26681.

36. Millner AJ, Ursano RJ, Hwang I, King A, Naifeh JA, Sampson NA, Zaslavsky AM, Stein MB, Kessler RC, Nock MK. Prior mental disorders and lifetime suicidal behaviors among U.S. Army soldiers in the Army study to assess risk and resilience in Servicemembers (Army STARRS). Suicide Life Threat Behav. (Epub ahead of print). https://www.ncbi.nlm.nih.gov/pubmed/28926674.

37. Ursano RJ, Kessler RC, Naifeh JA, Herberman Mash HB, Fullerton CS, Ng THH, Aliaga PA, Wynn GH, Dinh HM, McCarroll JE, et al. Suicide attempts in U.S. Army combat arms, special forces and combat medics. BMC Psychiatry. 2017;17(1):194. 
38. Hoge CW, Auchterlonie JL, Milliken CS. Mental health problems, use of mental health services, and attrition from military service after returning from deployment to Iraq or Afganistan. J Am Med Assoc. 2006;295:1023-32.

39. Ireland RR, Kress AM, Frost LZ. Association between mental health conditions diagnosed during initial eligibility for military health care benefits and subsequent deployment, attrition, and death by suicide among active duty service members. Mil Med. 2012;177(10):1149-56.

40. Warner CH, Appenzeller GN, Parker JR, Warner CM, Hoge CW. Effectiveness of mental health screening and coordination of in-theater care prior to deployment to Iraq: a cohort study. Am J Psychiatry. 2011;168:378-85.

41. Griffith J, Bryan CJ. Preventing suicides in the US military. Psychol Serv. 2018; 15(3):251-61.

42. Greden JF, Valenstein M, Spinner J, Blow A, Gorman LA, Dalack GW, Marcus S, Kees M. Buddy-to-buddy, a citizen soldier peer support program to counteract stigma, PTSD, depression, and suicide. Ann N Y Acad Sci. 2010; 1208:90-7.

Ready to submit your research? Choose BMC and benefit from:

- fast, convenient online submission

- thorough peer review by experienced researchers in your field

- rapid publication on acceptance

- support for research data, including large and complex data types

- gold Open Access which fosters wider collaboration and increased citations

- maximum visibility for your research: over $100 \mathrm{M}$ website views per year

At $\mathrm{BMC}$, research is always in progress.

Learn more biomedcentral.com/submissions 